DOI: https://doi.org/10.24127/ajpm.v10i4.3767

\title{
EKSPLORASI KEMAMPUAN PEMECAHAN MASALAH MATEMATIS SISWA PADA MATERI PERBANDINGAN BERDASARKAN KEMAMPUAN MATEMATIKA
}

\author{
Ervin Azhar ${ }^{*}$, Yana Saputra ${ }^{2}$, Ishaq Nuriadin ${ }^{3}$ \\ ${ }^{1,2}$ Universitas Muhammadiyah Prof. DR. HAMKA, Jakarta \\ E-mail: $\quad$ ervin.azhar.matematika@uhamka.ac.id $^{\left.{ }^{*}\right)}$ \\ yana87@uhamka.ac.id ${ }^{2)}$ \\ ishaq_nuriadin@uhamka.ac.id ${ }^{3)}$
}

Received 29 May 2021; Received in revised form 13 September 2021; Accepted 13 December 2021

\begin{abstract}
Abstrak
Pemecahan masalah matematis menuntut seseorang berpikir sistematis, logis, kritis dan pantang menyerah sampai menemukan solusi dari sebuah permasalahan yang dihadapi. Penelitian ini bertujuan untuk mengetahui profil kemampuan pemecahan masalah matematis siswa materi perbandingan. Hasil penenlitian ini dapat dijadikan masukan untuk mengoptimalkan kemampuan pemecahan masalah matematis siswa sehingga guru dapat mengkontruksi pembelajaran yang dapat meningkatkan kemampuan pemecahan masalah matematis. Penelitian dilakukan dengan desain penelitian kualitatif deskriptif. Subjek penelitian yaitu siswa kelas VII-B SMP Kebangsaan Pondok Aren Tahun Pelajaran 2020/2021. Data yang diperoleh dari hasil tes dan wawancara kemudian dianalisis untuk menggambarkan kemampuan pemecahan masalah matematis siswa ditinjau dari kemampuan matematis. Hasil penelitian menunjukan bahwa siswa dengan kemampuan matematis tinggi telah memenuhi tahapan Polya menyelesaikan permasalahan mampu memahami masalah, menyusun rencana penyelesaian dan melaksanakan rencana, dan memeriksa jawaban kembali. Sedangkan siswa kemampuan matematis sedang, dalam menyelesaikan permasalahan soal perbandingan siswa mampu memahami masalah namun kurang dalam merencanakan masalah meskipun dalam melakukan prosedur sudah tepat. Sementara siswa dengan kemapuan matematis rendah, hanya mampu pada tahap memahami masalah tetapi kesulitan dalam merencanakan, melaksanakan rencana. Sehingga perlu menjadi perhatian pendidik khusunya dalam meningkatkan kemampuan pemecahan masalah siswa sedang dan rendah.
\end{abstract}

Kata Kunci: Kemampuan matematika; kemampuan pemecahan masalah.

\begin{abstract}
Solving mathematical problems requires someone to think systematically, logically, critically and never give up until finding a solution to a problem at hand. This study aims to determine the profile of students' mathematical problem solving abilities in comparative material. The results of this research can be used as input to optimize students' mathematical problem solving skills so that teachers can construct learning that can improve mathematical problem solving abilities. The research was conducted with a descriptive qualitative research design. The research subjects are students of class VII-B SMP Kebangsaan Pondok Aren in the academic year 2020/2021. The data obtained from the results of tests and interviews were then analyzed to describe students' mathematical problem solving abilities in terms of mathematical abilities. The results showed that students with high mathematical abilities had fulfilled the Polya stages of solving problems, being able to understand problems, develop plans for completion and implement plans, and check answers again. While students with moderate mathematical ability, in solving problems of comparison students are able to understand the problem but are less able to plan problems even though they carry out the correct procedure. Meanwhile, students with low mathematical ability are only able to understand the problem but have difficulty in planning and implementing plans. So it needs to be a concern for educators, especially in improving the problem-solving abilities of moderate and low students.
\end{abstract}

Keywords: Mathematical ability; problem solving ability. 


\section{PENDAHULUAN}

Berkembangnya teknologi dalam proses pembelajaran matematika bertahap mengubah fokus pendidikan matematika yang awalnya prestasi belajar matematika menjadi peningkatan berbagai kemampuan siswa (Kosiret et al., 2021; Tan \& Ang, 2016; Umam \& Kowiyah, 2018). Hasil akhir diperoleh dari penilaian berupa skor prestasi belajar, namun hendaknua dalam pembelajaran berusaha untuk meningkatkan berbagai kemampuan lain seperti pemecahan masalah, komunikasi, berpikir kritis, berpikir reflektif serta kreatif (Sanders, 2016; Umam, 2018). Hal tersebut sejalan dengan 5 standar pembelajaran matematika menurut NCTM diantaranya problem solving, reasoning and proff, connection, communication dan representasi (NCTM, 2000).

Pemecahan masalah matematis menuntut seseorang berpikir sistematis, logis, kritis dan pantang menyerah sampai menemukan solusi dari sebuah permasalahan yang dihadapi. Bahkan NCTM menyatakan bahwa kemampuan pemecahan masalah merupakan harapan dan tujuan utama dalam pelajaran matematika (Dahar, 2011; NCTM, 2000). Sisi lain pembelajaran matematika dapat memberikan keterampilan maupun kemampuan siswa dalam memecahkan masalah kehidupan sehari-hari. Dengan demikian matematika merupakan alat dalam melatih siswa supaya mampu memecahkan permasalah, serta membangun proses berpikir mengarah kemampuan lanjutan dalam memecahkan masalah diluar matematika (Ike \& Suhendri, 2021; Mardhiyana \& Sejati, 2016; Nabilah et al., 2021; Phonapichat et al., 2014). Selain itu, pemecahan masalah merupakan keterampilan seseorang untuk menganalisis, memprediksi, menalar, evaluasi serta merefleksikan (Anderson, 2014; Hendriani et al., 2016). Dalam pemecahan masalah melibatkan pengetahuan serta pengalaman yang dimiliki. Senada dengan pendapat Mulyati dan Sabarudin bahwa pemecahan masalah merupakan suatu kemampuan untuk menggunakan pengetahuan sebelumnya dalam menyelesaikan masalah di situasi yang baru sehingga siswa berusaha dengan baik dalam mencari solusi (Mulyati, 2016; Sabaruddin, 2019). Dunia pendidikan memberikan ruang serta kesempatan kepada siswa untuk meningkatkan berbagai kemampuan berpikir. Kemampuan tersebut dapat dilatih dengan masalah.

Kenyataanya studi terbaru dari Programme for International Student Assessment (PISA) pada tahun 2018 dimana studi tersebut membandingkan kemampuan matematika, membaca serta kinerja sains dari 600.000 anak yang berusia 15 tahun yang berasal dari 79 negara. Hasil studi yang telah publikasikan hari Selasa, 3 Desember 2019 bahwa matematika Indonesia berada pada peringkat 73 dari 79 negara (Schleicher, 2018; Tohir, 2019). Selain itu pada tahun yang sama, PRISE di Indonesia merilis studi yang menyatakan kemampuan pemecahan soal matematika yang sederhana ternyata tidak berbeda jauh antara siswa baru masuk SD dengan siswa yang sudah tamat SMA (Ikram \& Ikram, 2021; Okenews, 2018; Saida et al., 2021). Hal tersebut tentunya harus menjadi perhatian kita bersama khusunya para pendidik dalam meningkatkan kemampuan matematika siswa maupun kemampuan membaca.

Banyak penelitian terkait kesulitan-kesulitan siswa dalam memecahkan masalah matematika. 
Hasil temuan mengenai kesulitan siswa dalam pemecahan masalah diantaranya multi tafsir terhadap soal yang diberikan (Fauzi, 2018). Kurangnya pengetahuan serta pemahaman siswa ketika melakukan operasi hitung, bagi siswa yang memiliki kemampuan rendah akan melakukan operasi hitung secara acak tanpa mengetahui prosedur yang benar (Indra et al., 2019; Karim et al., 2021; Zhang et al., 2014). Kendala terbesar dalam pemecahan masalah adalah kurangnya keterampilan membaca, komputasi dan kemampuan matematika. Saat siswa kurang memahami teks yang tersirat, mereka kesulitan untuk memulai proses berpikir dalam pemecahkan masalah. Mereka mengetahui kata kunci sangat terbatas. Siswa kurang tertarik soal matematika, dengan alasan soal panjang serta kompleks. Peneliti lain juga mempelajari hubungan pemahaman membaca dengan prestasi matematika, seperti Helwig (1999), Fuchs (2000), sebuah studi tentang indikator-indikator yang mempengaruhi pembelajaran matematika menunjukkan bahwa itu adalah kunci faktor membaca (Lamb, 2010; Ranti et al., 2017). Sehingga pembelajaran perlu dirancang agar dapat mengakomodasi semua karakter peserta didik (Assidiqi, 2015; Karim et al., 2021; Purwanto, 2014).

Materi perbandingan salah satu yang diajarkan kepada siswa kelas VII sesuai dengan kurikulum 2013 revisi. Tidak sedikit siswa melakukan kekeliruan dan kesalahan dalam mengerjakan soal cerita perbandingan. Hal ini dikuatkan hasil penelitian Lewier dkk bahwa pada siklus I diperoleh 24,14 siswa tuntas sementara $75,87 \%$ siswa belum tuntas (Kurniasih et al., 2021; Lewier et al., 2019). Siswa kurang terampil dalam proses memecahkan masalah, baik secara konsep maupun prosedural. Pemecahan masalah merupakan cara berpikir yang sistematis secara langsung dengan tujuan untuk menemukan solusi dari permasalahan yang ada. Pemecahan masalah merupakan pemikiran terarah untuk menentukan solusi/jalan keluar suatu masalah secara spesifik (Maulidya, 2018; Mawaddah \& Anisah, 2015). Senada dengan pemecahan masalah termasuk kecakapan atau potensi siswa untuk menyelesaiakan permasalahan maupun mengaplikasikan di kehidupan sehari-hari (Achsin, 2015; Gunantara, 2014; Saida et al., 2021).

Dari penjelasan di atas yang telah disebutkan bahwa pemecahan masalah matematis memerlukan berbagai kemampuan diantaranya memahami masalah, kemampuan bernalar serta berpikir kritis. Permasalahan yang terjadi di sekolah ketika guru hanya memberikan informasi dan tidak dapat memberikan banyak kesempatan kepada siswa dalam menyampaikan idenya ketika pembelajaran berlangsung (Huriaty Dina, 2010; Nuriadin et al., 2015). Menjadi pertanyaan peneliti yaitu bagaimana tingkat kemampuan pemecahan masalah siswa pada materi perbandingan?. Kemampuan pemecahan masalah yang masih kurang perlu pengkajian lanjutan mengenai profil kemampan pemecahan masalah matematis siswa materi perbandingan di MTs Al-Khairiyah Jakarta Selatan.

\section{METODE PENELITIAN Jenis Penelitan}

Jenis penelitian yang digunakan yaitu deskriptif kualitatif guna mendeskripsikan profil kemampuan pemecahan masalah siswa pada materi perbandingan ditinjau dari kamampuan matematis. Siswa terlebih dahulu dibagi menjadi tiga kelompok berdasarkan 
kemampuan matematis, kemudian diberikan soal perbandingan yang berisi soal cerita untuk mengetahui profil kemampuan pemecahan masalah masing-masing kelompok. Hasil dari jawaban siswa kemudian dianalisis berdasarkan indikator kemampuan pemecahan masalah. (mengapa termasuk kategori kualitatif)

\section{Pemilihan subjek}

Subjek dalam penelitian ini adalah seluruh siswa kelas VII-B SMP Kebangsaan Pondok Aren tahun ajaran 2020/2021. Jumlah siswa sebanyak 34, kemudian dikelompokan berdasarkan kemampuan matematis. Pengelompokan berdasarkan nilai rata-rata ulangan harian siswa pada materi sebelumnya. Subjek yang dipilih sebanyak tiga siswa yang telah memenuhi kriteria sebagai siswa yang memiliki kemampuan matematis tinggi, sedang dan rendah yang disimbolkan Tabel 1.

Tabel 1. Demografi Sampel

\begin{tabular}{clcc}
\hline \multicolumn{2}{c}{ Kategori } & Jumlah & $\%$ \\
\hline Gender & Laki-laki & 16 & $47 \%$ \\
\cline { 2 - 4 } & Perempuan & 18 & $53 \%$ \\
\hline $\begin{array}{c}\text { Kemampuan } \\
\text { Matematis } \\
\text { Siswa }\end{array}$ & Tinggi & 7 & $21 \%$ \\
\cline { 2 - 4 } & Sedang & 17 & $50 \%$ \\
\cline { 2 - 4 } Belajar \\
Matematika \\
$\begin{array}{c}\text { selama } \\
\text { pandemik } \\
\text { dengan }\end{array}$ & Handphone & 10 & $29 \%$ \\
\cline { 2 - 4 } & & 7 & $79 \%$ \\
\hline
\end{tabular}

\section{Tekik Pengambalian Data}

Pengambilan data dilakukan dengan cara memberikan soal kepada tiga siswa kelas VII-B SMP Kebangsaan Pondik Aren yang memiliki kemampuan matematis tinggi, sedang dan rendah setelah pembelajaran materi perbandingan. Dari hasil pengerjaan siswa diperoleh jawaban atas soal yang diberikan. Soal dan jawaban sebagai data penelitian kemudian dianalisis berdasarkan indikator kemampuan pemecahan masalah (Tabel 2) yaitu 1) Memahami masalah, 2) Menyusun Rencana, 3) Melaksanakan perencanaan, dan 4) Memeriksa kembali. Dari hasil analisis data kemudian dideskripsikan profil kemampuan pemecahan masalah siswa.

\section{Instrumen Penelitian}

Instrumen utama dalam penelitian ini adalah peneliti itu sendiri, sementara instrumen pendukung yaitu tes kecerdasan majemuk yang diambil dari buku "born to be a genius" untuk mengetahui subjek yang memiliki kemampuan matematis tinggi, sedang dan rendah. Kemudian diberikan tes tertulis tentang materi perbandingan dalam bentuk uraian. Tes tertulis tersebut berisi tentang bagaimana memahami masalah (MM), menyusun rencana (MR), melaksanakan perencanaan (MP), dan memeriksa kembali (MK). Berikut instrument yang digunakan "Perbandingan uang Depsya dan Inasya adalah $2: 3$, sementara perbandingan uang Inasya dan Elisya adalah 4 : 5. Jika jumlah uang ketiga anak tersebut Rp3.500.000,-. Berapakah uang masing-masing anak tersebut?"

Tabel 2. Indikator Pemecahan Masalah Menurut Polya

\begin{tabular}{|c|c|}
\hline Indikator & $\begin{array}{c}\text { Kriteria Kegiatan } \\
\text { Kontruksi } \\
\text { Pengetahuan }\end{array}$ \\
\hline $\begin{array}{l}\text { Memahami } \\
\text { Masalah }\end{array}$ & $\begin{array}{l}\text { Siswa mampu } \\
\text { mengidentifikasi } \\
\text { permasalahan dengan } \\
\text { menunjukan yang } \\
\text { diketahui, ditanya serta } \\
\text { kelengkapan unsur } \\
\text { yang dibutuhkan. }\end{array}$ \\
\hline
\end{tabular}


DOI: https://doi.org/10.24127/ajpm.v10i4.3767

\begin{tabular}{|c|c|}
\hline Indikator & $\begin{array}{c}\text { Kriteria Kegiatan } \\
\text { Kontruksi } \\
\text { Pengetahuan }\end{array}$ \\
\hline $\begin{array}{l}\text { Menyusun } \\
\text { Rencana }\end{array}$ & $\begin{array}{l}\text { Siswa mampu } \\
\text { menentukan rumus } \\
\text { atau cara awal } \\
\text { penyelesaian, dapat } \\
\text { melakukan } \\
\text { penyelidikan untuk } \\
\text { pemecahan masalah }\end{array}$ \\
\hline $\begin{array}{c}\text { Melaksanakan } \\
\text { Rencana }\end{array}$ & $\begin{array}{l}\text { Siswa melaksanakan } \\
\text { rencana dengan } \\
\text { melakukan } \\
\text { penyelesaian sesuai } \\
\text { langkah yang } \\
\text { direncanakan }\end{array}$ \\
\hline $\begin{array}{l}\text { Memeriksa } \\
\text { Kembali }\end{array}$ & $\begin{array}{l}\text { Siswa memeriksa } \\
\text { kembali hasil } \\
\text { penyelesaian untuk } \\
\text { memastikan langkah } \\
\text { pengerjaan sesuai } \\
\text { dengan prosedur. }\end{array}$ \\
\hline
\end{tabular}

\section{Analisis Data Penelitian}

Analisis data dilakukan melalui beberapa tahapan. Adapun tahapan menganalisis data yaitu: mempelajari data, mengklasifikasikan dan menentukan profil. Tahap mempelajari data, dilakukan dengan cara : Pengumpulan hasil pekerjaan siswa dari tugas yang diberikan, menelaah dan membaca hasil pekerjaan siswa, untuk diperoleh dugaan awal tentang: bagaimana cara siswa dalam menyelesaikan soal, informasi apa saja yang digunakan siswa sebagai acuan dalam penyelesaian soal. Tahap mengklasifikasikan data hasil kerjaan siswa dianalisis berdasarkan indikator kemampuan pemecahan masalah, sedangkan hasil wawancara dianalisis dengan teknik yang dinyatakan Miles dan Huberman (1994) yaitu reduksi data, penyajian data dan penarikan kesimpulan (Miles \& Huberman, 1994). Tahap terakhir menentukan profil siswa dari hasil jawaban soal yang diajukan, yakni bagaimana memahami masalah (MM), menyusun rencana (MR), melaksanakan perencanaan (MP), dan memeriksa kembali (MK).

\section{HASIL DAN PEMBAHASAN}

\section{Profil Kemampuan Masalah Siswa Berkemampuan Tinggi}

\section{Memahami Masalah}

Saat S1 diberikan soal, S1 terlihat membaca dengan teliti dari keseluruhan informasi soal. Kemudian terlihat termenung dengan memegang kepala, namun tetap mencoba membuat coretan di buku tulis. Hal tersebut diduga S1 mencoba mengingat kembali jenis soal dan cara pengerjaan yang telah dipelajari sebelumnya. Petikan hasil wawancara peneliti dengan S1 sebagai berikut :

$\mathrm{P} \quad$ : Apa yang kamu pikirkan saat melihat soal tersebut? (MMP001)

S1 : Ini soal tentang perbandingan Pak, tapi saya lagi ingat-ingat cara ngerjainya (MMS1001)

$\mathrm{P}$ : Informasi apa saja yang kamu peroleh dari soal tersebut? (MMP002)

S1 : Ada perbandingan uang dari 3 orang anak Pak (MMS1002)

$\mathrm{P}$ : Oke, apakah sekarang sudah memahami permasalahan pada soal tersebut? (MMP003)

S1 : Alhamdulillah sudah Pak, saya ingat contoh yang pernah diberikan Bapak, (MMS1003)

S1 dengan kelompok kemampuan matematis tinggi dapat menunjukkan proses memahami masalah. Terlihat coretan pada soal yang diberikan, menunjukan unsurunsur yang terdapat pada soal tersebut. Langkah memahami masalah pada materi perbandingan $\mathrm{S} 1$ secara umum 
mampu memahami masalah dengan sangat baik (MMS1003). S1 menyebutkan yang diketahui dan ditanya dengan tepat. Hal ini selaras dengan hasil analisis Andriyani bahwa siswa yang dapat memahami masalah dengan baik jika mampu menyusun dan mengidentifikasi unsur/objek yang belum terorganisir (Andriyani \& Ratu, 2018; Yarmayani, 2016).

\section{Menyusun Rencana}

Menyusun rencana S1 mencoba menggunakan simbol-simbol dalam bentuk variabel. S1 mencoba menuliskan perbandingan 2 anak dengan variabel, kemudian menuliskan perbandingan 2 anak berikutnya sesuai informasi soal. Hal ini ia lakukan untuk mempermudah dalam pengelompokan perbandingan. Kemudian menghubungkanya guna menyesuaikan dengan rumus yang diingat. Berikut petikan hasil wawancara dengan S1 :

P : Dari soal tersebut, hal apa yang pertama kamu tuliskan? (MRP004)

S1 : Saya menulis semua yang diketahui dari soal Pak. Itu kan ada perbandingan uang 2 orang anak ya. (MRS1004)

$\mathrm{P}$ : Setelah itu, rencana selanjutnya apa? (MRP005)

S1 : Semua yang dketahui sudah saya tulis, baru deh tulis rumus umum perbandingan yang Bapak pernah berikan (MRS1005)

$\mathrm{P} \quad$ : Mengapa dalam mengerjakan soal ini kamu tulis semua yang diketahui dan menuliskan rumusnya? (MRP006)

S1 : Untuk memudahkan dalam memahami soal Pak, kalau sudah paham kan gampang cara ngerjainya, hehe. (MRS1006)

Menyusun rencana dalam pemecahan masalah perbandingan secara umum S1 dikategorikan baik. S1 terlihat menyusun rencana dengan mengaitkan informasi dari soal dengan rumus yang pernah dipelajari serta mengarah kepada solusi yang tepat (MRS1005). Salah satu yang bisa diamati dalam menyusun rencana yang benar, jika terlihat siswa melakukan tindakan menuju solusi yang benar dalam pemecahan masalah (Akbar et al., 2017; Tisngati, 2015).

\section{Melaksanakan Perencanaan}

S1 setelah mencoba untuk menyusun rencana ia melanjutkan dengan memasukan nilai-nilai yang diketahui kedalam rumus. S1 menempatkan nilai dengan tepat kepada rumus serta melakukan operasi matematika dengan baik. S1 melakukan pengerjaan sesuai prosedur dengan tepat sehingga mampu menjawab soal tersebut dengan benar. Hal ini dapat terlihat dari hasil wawancara dengan S1 yaitu sebagai berikut :

$\mathrm{P}$ : Setelah menulis semua yang diketahui dan rumus, langkah selanjutnya? (MPP007)

S1 : masukin semua nilai yang diketahui ke rumus Pak, terus hitung deh. (MPS1007)

P : Dalam perhitungan, kamu termasuk anak yang teliti atau kadang terburuburu? (MPP008)

S1 : hehe, kadang kalau sudah tahu caranya, menghitung suka masih salah. (MPS1008)

$\mathrm{P}$ : Nah loh, tahu salah dari mana? (MPP009)

S1 : Biasanya saya cek ulang hasil perhitungan saya Pak, jadi tahu salah atau benarnya. (MPS1009)

Dalam melaksanakan rencana dalam pemecahan masalah pada materi perbandingan, S1 dikategorikan baik. S1 mampu melakukan operasi hitung matematika dengan baik serta 
menggunakan langkah-langkah yang benar (MPS1007). Analisis kemampuan melaksanakan rencana dapat diterlihat pada proses pemecahan masalah secara sadar serta berkala menunjukan kemajuan dalam pemecahan masalah, serta dapat memperlihatkan perbaikan sehingga mampu menjawab dengan benar (Erbas \& Okur, 2012; Sari \& Maidiyah, 2019).

\section{Memeriksa Kembali}

Dari hasil percakapan sebelumnya, terlihat bahwa S1 setelah selesai mengerjakan sering cek ulang khususnya proses perhitungan yang ia lakukan. Sehingga S1 termasuk anak dalam kategori memeriksa kembali dalam melakukan proses pemecahan soal yang diberikan. Berikut hasil percakapan wawancara dengan $\mathrm{S} 1$ :

P : Jawaban yang kamu kerjakan benar, (MKP0010)

S1 : Alhamdulillah Pak (MKS10010)

$\mathrm{P}$ : Apakah setiap mengerjakan soal matematika, sebelum kamu kumpulkan selalu dikoreksi dulu? (MKP0011)

S1 : Ya Pak, untuk memastikan tidak ada yang salah menghitung. (MKS10011)

$\mathrm{P}$ : Bagaimana cara kamu dalam memeriksa kembali hasil pekerjaan? (MKP0012)

S1 : Biasanya saya cek ulang hasil pekerjaan dari awal dan perhitungan saya Pak, jadi tahu salah atau benarnya.(MKS10012)

Memeriksa kembali yang dilakukan oleh S1 adalah mengecek dari awal pengerjaan sampai selesai (MKS10012). Baik itu rumus maupun operasi hitung matematika yang telah dilakukan. Sehingga S1 tergolong kedalam siswa yang telah melakukan proses memeriksa kembali dalam pemecahan masalah matematis.
Individu yang telah yakin dengan hasil pekerjaannya dengan ditandai proses pengecekan baik prsedur maupun operasi hitung termasuk memenuhi indikator memerika kembali dalam pemecahan masalah (Argarini, 2018; Yarmayani, 2016).

\section{Profil Kemampuan Masalah Siswa Berkemampuan Sedang}

\section{Memahami Masalah}

Langkah dalam memahami masalah S2 dapat memahami masalah yang diberikan, namun tidak terlihat hal penting dari soal yang Ia tandai. Dalam memahami masalah S2 terlihat dari langkah selanjutnya yaitu membuat rencana dengan menuliskan semua yang diketahui dan ditanyakan dari soal serta diperkuat dengan wawancara. Petikan hasil wawancara peneliti dengan S2 sebagai berikut :
$\mathrm{P}$ : Apa yang kamu pikirkan saat melihat soal tersebut? (MMP001)
S2 : Mencari uang masing-masing Pak (MMS2001)
$\mathrm{P}$ : Informasi apa saja yang kamu peroleh dari soal tersebut? (MMP002)

S2 : Diketahui perbandingan uang ketiga anak dan jumlah uang seluruhnya (MMS2002)

$\mathrm{P}$ : Oke, apakah sekarang sudah memahami permasalahan pada soal tersebut? (MMP003)

S2 : Untuk masalah paham Pak, namun masih mikir cara ngerjainya, hehe, (MMS2003)

Setidaknya dalam memahami soal S2 melakukan dengan membaca berulang, kemudian mengungkapkan yang diketahui namun tidak menuliskan yang ditanyakan dari soal (MMS2003). Subjek pada kategori kemampuan matematis sedang memiliki perbedaan dalam tahap memahami masalah, diantaranya dalam memahami masalah 
ada subjek membaca dua kali atau bahkan lebih dari dua kali. Hal ini sejalan dengan hasil penelitian Mairing bahwa dalam memahami masalah setidaknya subjek membaca minimal dua kali (Mairing et al., 2011; Risani \& Nuriyatin, 2021).

\section{Menyusun Rencana}

S2 menuliskan hal-hal penting dari soal namun tidak menuliskan rencana pemecahan masalah. Alasan S2 tidak menuliskan dalam menyusun rencana dikarenakan lupa rumus perbandingan, namun dalam memasukan nilai yang diketahui dari soal S2 melakukanya dengan benar. Berikut petikan hasil wawancara dengan S2 :

\section{P : Dari soal tersebut, hal apa yang pertama kamu tuliskan? (MRP004) \\ S2 : Saya tulis yang diketahui dari soal Pak. (MRS2004) \\ $\mathrm{P}$ : Setelah itu, rencana selanjutnya apa? (MRP005) \\ S2 : Gunakan rumus perbandingan untuk mencari masing-masing uang mereka. (MRS2005) \\ $\mathrm{P} \quad$ : Kenapa tidak terlihat rumus dalam menyusun rencana? (MRP006) \\ S2 : Rumus pastinya saya lupa Pak, namun kalau memasukan angkanya sepertinya saya ingat. (MRS2006)}

Dalam menyusun rencana S2 terlihat hanya menuliskan yang diketahui dan ditanya tanpa menuliskan rumus yang akan digunakan (MRS2006). Namun dari hasil analisis wawancara S2 dapat menggunakan perhitungan dengan benar yaitu dengan membuat langkah pengerjaan dalam melakukan perhitungan. Perilaku yang dilakukan S2 dalam membuat rencana dapat terjadi dengan mengenali, merangkai dan mengkontruksi (Hershkowitz et al., 2007; Saputri, 2019).

\section{Melaksanakan Perencanaan}

Langkah melaksanakan rencana S2 langsung memasukan nilai yang diketahui sesuai dengan pengetahuan awal yang telah dimiliki. Meskipun dalam membuat rencana tidak menuliskan rumus, dalam perhitungan yang dilakukan S2 sudah benar sesuai prosedurHal ini dapat terlihat dari hasil wawancara dengan S2 yaitu sebagai berikut :

$\mathrm{P} \quad$ : Kaтu kan tidak menuliskan atau tidak hafal rumus, dalam melakukan perhitungan apa yang kamu lakukan? (MPP007)

S2 : Saya hanya inget dalam perbandingan itu perbandingan yang dicari dibagi perbandingan diketahui, terus kali dengan nilainya Pak. Benar ga ya?. (MPS2007)

P : Nah itu kalau dari perkataan kamu betul loh, tapi kenapa rumus lupa, padahal kalau disampaikan kata-kata sudah betuk (MPP008)

S2 : Lupa Pak kalau tulis rumus. (MPS2008)

Melaksanakan rencana dalam pemecahan masalah pada materi perbandingan, S2 dikategorikan baik. S2 mampu melakukan operasi hitung matematika dengan baik serta menggunakan langkah-langkah yang benar (gambar 3). Kemampuan melaksanakan rencana dapat diterlihat pada proses pemecahan masalah secara sadar serta berkala menunjukan kemajuan dalam pemecahan masalah, serta dapat memperlihatkan perbaikan sehingga mampu menjawab dengan benar (Erbas \& Okur, 2012; Sari \& Maidiyah, 2019). 
DOI: https://doi.org/10.24127/ajpm.v10i4.3767

\section{Memeriksa Kembali}

Dari hasil percakapan, S2 tidak melakukan proses pengecekan kembali. Sehingga S2 termasuk anak dalam kategori tidak memeriksa kembali dalam melakukan proses pemecahan soal yang diberikan. Berikut hasil percakapan wawancara dengan S2:

P : Tadi sebelum dikumpulkan, apakah kamu memeriksa kembali hasil yang sudah dikerjakan?, (MKP009)

S2 : Hehe, saya tipe orang kalau sudah selesai tidak di cek lagi Pak, maaf (MKS2009)

$\mathrm{P} \quad$ : Lantas bagaimana kalau ada salah dalam perhitungan? (MKP0010)

S2 : Saya berusaha teliti dari setiap proses perhiutng Pak, itulah alasan kenapa tidak di cek lagi. (MKS20010)

Langkah terakhir dalam memeriksa kembali, S2 tidak melakukan itu (MKS20010). Karena merasa jawaban yang sudah dikerjakan dan Ia buat benar. Siswa dengan kemampuan matematis sedang tidak melakukan proses memeriksa kembali (Irianti, 2020; Rani \& Istiqomah, 2019).

\section{Profil Kemampuan Masalah Siswa Berkemampuan Rendah}

\section{Memahami Masalah}

Langkah dalam memahami masalah S3 dapat memahami masalah yang diberikan dengan cara membaca berulang-ulang dari informasi yang diberikan. Dalam memahami masalah S3 menuliskan informasi yang ada pada soal baik yang diketahui maupun yang ditanya. Petikan hasil wawancara peneliti dengan S3 sebagai berikut :
$\mathrm{P}$ : Apa yang kamu pikirkan saat melihat soal tersebut? (MMP001)

S3 : Materi tentang perbandingan Pak. (MMS3001)

$\mathrm{P}$ : Informasi apa saja yang kamu peroleh dari soal tersebut? (MMP002)

S3 : Ada perbandingan jumlah uang ketiga anak (MMS3002)

$\mathrm{P}$ : Oke, apakah sekarang sudah memahami permasalahan pada soal tersebut? (MMP003)

S3 : Dari soal saya paham Pak, tapi ga tahu cara mengerjakanya, hehe (MMS3003)

Setidaknya dalam memahami soal S3 berusaha dengan melakukan membaca berulang, kemudian mengungkapkan yang diketahui dan ditanyakan dari soal (MMS3003). Subjek pada kategori kemampuan matematis rendah berusaha memahami masalah, diantaranya dalam memahami masalah ada subjek membaca dua kali atau bahkan lebih dari dua kali. Hal ini sejalan dengan hasil penelitian Mairing bahwa dalam memahami masalah setidaknya subjek membaca minimal dua kali (Mairing et al., 2011; Risani \& Nuriyatin, 2021).

\section{Menyusun Rencana}

S3 menuliskan hal-hal penting dari soal namun tidak menuliskan rencana pemecahan masalah. Alasan S3 dia lupa rumus perbandingan. Berikut petikan hasil wawancara dengan S3 :

P : Dari soal tersebut, hal apa yang pertama kamu tuliskan? (MRP004)

S3 : Tulis diketahui dan ditanya Pak. (MRS3004)

$\mathrm{P}$ : Setelah itu, rencana selanjutnya apa? (MRP005)

S3 : Untuk mencari hasil yaitu menggunakan rumus, tapi ini saya lupa. (MRS3005) 
Dalam menyusun rencana S3 terlihat hanya menuliskan yang diketahui dan ditanya tanpa menuliskan rumus yang akan digunakan (MRS3004). S3 tidak memenuhi tahap menyusun rencana karena S3 hanya menuliskan sedikit fakta yang terdapat di soal. Tahapan menyusun rencana tidak terpenuhi apabila hanya mampu menuliskan informasi saja dari soal, dikarenakan kurang memahami konse (Maarif et al., 2020; Wahyu Hidayat, 2018; Widodo, 2013).

\section{Melaksanakan Perencanaan}

Langkah melaksanakan rencana S3 hanya mencoba-coba dari informasi angka yang diketahui dalam soal, tanpa mengetahui prosedur tersebut benar atau salah. Hal ini dapat terlihat dari hasil wawancara dengan S3 yaitu sebagai berikut :

$\mathrm{P} \quad$ :Kamu kan tidak menuliskan atau tidak hafal rumus, dalam melakukan perhitungan apa yang kamu lakukan? (MPP006)

S3 : Saya coba-coba aja Pak, dari angka yang ada di soal. (MPS3006)

$\mathrm{P}$ : Oalah, kenapa seperti itu? (MPP007)

S3 : Saya benar-benar lupa Pak, rumus apa yang harus digunakan. (MPS3007)

Dalam melaksanakan rencana dalam pemecahan masalah pada materi perbandingan, S3 dikategorikan kurang. S3 tidak mampu melakukan prosedur yang benar sesuai dengan penyelesaian yang seharusnya dilakukan (MPS3007). Sejalan dengan penelitian Selvy bahwa siswa quitters dengan tidak dapat melakukan perencanaan masalah dalam melaksanakan dengan baik, karena terkendala pada proses memahami masalah, membuat rencana serta rendahnya kemampuan matematika menyebabkan kesalahan dalam memahami masalah. (Abdiyani et al., 2019; Irianti et al., 2016; Nabilah et al., 2021; Nuriadin, 2021).

\section{Memeriksa Kembali}

Dari hasil percakapan, S3 melakukan proses pengecekan kembali dalam proses perhitungan. S3 merasa kebingungan dengan apa yang Ia kerjakan benar atau salah, namun Ia berusaha untuk mengecek hasil perhiutngan saja. Berikut hasil percakapan wawancara dengan S3:

P : Tadi sebelum dikumpulkan, apakah kamu memeriksa kembali hasil yang sudah dikerjakan?, (MKP008)

S3 : Saya tidak yakin yang saya kerjakan benar atau salah, tapi saya mencoba memeriksa hasil itungan saja Pak (MKS3008)

P : Lantas bagaimana kalau ada salah dalam perhitungan? (MKP009)

S3 : Saya perbaiki Pak. (MKS3009)

Langkah terakhir dalam memeriksa kembali, S3 tergolong kedalam siswa yang telah melakukan proses memeriksa kembali dalam pemecahan masalah matematis (MKS3008). Individu yang telah yakin dengan hasil pekerjaannya dengan ditandai proses pengecekan baik prosedur maupun operasi hitung termasuk memenuhi indikator memerika kembali dalam pemecahan masalah (Argarini, 2018; Yarmayani, 2016). Hasil analisis kemampuan matematika siswa tingkat tinggi, sedang, dan rendah dirangkum pada Tabel 3. 
Tabel 3. Hasil analisis kemampuan matematika siswa tingkat tinggi, sedang, dan rendah

\begin{tabular}{|c|c|c|c|}
\hline & \multicolumn{3}{|c|}{ Kemampuan Matematika Siswa Tingkat } \\
\hline & Tinggi & Sedang & Rendah \\
\hline MM & $\begin{array}{c}\text { Memahami soal } \\
\text { dengan baik ditandai } \\
\text { dengan menuliskan } \\
\text { semua yang dikethaui } \\
\text { dan ditanya dengan } \\
\text { akurat } \\
\end{array}$ & $\begin{array}{c}\text { Setidaknya memahami soal } \\
\text { dengan membaca berulang, } \\
\text { mengungkapkan apa yang } \\
\text { diketahui tetapi tidak } \\
\text { menuliskan apa yang } \\
\text { ditanyakan dari soal } \\
\end{array}$ & $\begin{array}{c}\text { Mampu menggambarkan } \\
\text { masalah dipahami dan apa } \\
\text { yang diketahui serta } \\
\text { ditanyakan. Informasi yang } \\
\text { diungkapkan tidak dengan } \\
\text { ragu-ragu } \\
\end{array}$ \\
\hline MR & $\begin{array}{c}\text { Menuliskan rumus } \\
\text { yang akan digunakan } \\
\text { sesuai dengan apa } \\
\text { yang ditanya dengan } \\
\text { akurat. }\end{array}$ & $\begin{array}{c}\text { Tidak menuliskan rencana } \\
\text { pemecahan masalah tetapi } \\
\text { menuliskan fakta-fakta } \\
\text { penting yang terdapat } \\
\text { disoal }\end{array}$ & $\begin{array}{c}\text { Tidak menuliskan rencana } \\
\text { pemecahan masalah dan } \\
\text { hanya sedikit menuliskan } \\
\text { fakta-fakta yang terdapat } \\
\text { disoal }\end{array}$ \\
\hline MP & $\begin{array}{c}\text { Melakukan pemecahan } \\
\text { masalah dengan baik, } \\
\text { rapi dan benar dalam } \\
\text { operasi hitung serta } \\
\text { dapat menarik } \\
\text { kesimpulan dengan } \\
\text { benar. } \\
\end{array}$ & $\begin{array}{c}\text { Menuliskan pemecahan } \\
\text { masalah dengan rapi dan } \\
\text { dapat menarik kesimpulan } \\
\text { dengan benar } \\
\text { Langkahlangkah } \\
\text { penyelesian dapat } \\
\text { dilakukan dengan benar. }\end{array}$ & $\begin{array}{l}\text { Menuliskan pemecahan } \\
\text { masalah dan menarik } \\
\text { kesimpulan. Namun } \\
\text { prosedur yang dilakukan } \\
\text { belum tepat }\end{array}$ \\
\hline MK & $\begin{array}{c}\text { Memeriksa kembali } \\
\text { jawaban dari soal dan } \\
\text { yakin akan jawaban } \\
\text { yang didapat }\end{array}$ & $\begin{array}{c}\text { Tidak melakukan } \\
\text { memeriksa kembali } \\
\text { jawaban karena merasa } \\
\text { yakin akan jawaban yang } \\
\text { didapat }\end{array}$ & $\begin{array}{c}\text { Melakukan memeriksa } \\
\text { kembali jawaban } \\
\text { meskipun tidak tahu pasti } \\
\text { benar atau salah prosedur } \\
\text { yang telah dilakukan }\end{array}$ \\
\hline
\end{tabular}

\section{KESIMPULAN DAN SARAN}

Berdasarkan hasil penelitian
diperoleh bahwa siswa dengan kemampuan matematis tinggi telah memenuhi empat tahapan Polya dalam menyelesaikan masalah materi perbandingan. Memahami masalah ditunjukan dengan menuliskan yang diketahui serta ditanya. Menyusun rencana dan melaksanakan rencana dilakukan dengan prosedur yang benar serta tidak lupa memeriksa kembali hasil pekerjaanya kembali. Sedangkan siswa kemampuan matematis sedang, dalam menyelesaikan permasalahan soal perbandingan siswa mampu memahami masalah namun kurang dalam merencanakan masalah meskipun dalam melakukan prosedur sudah tepat. Sementara siswa dengan kemampuan matematis rendah, hanya mampu pada tahap memahami masalah tetapi kesulitan dalam merencanakan, melaksanakan rencana. Sehingga perlu menjadi perhatian pendidik khusunya dalam meningkatkan kemampuan pemecahan masalah siswa sedang dan rendah.

Berdasarkan pemaparan di atas, peneliti merekomendasikan kepada para pendidik agar membiasakan peserta didik dalam memecahkan masalah matematis. Hal tersebut dapat dilakukan secara berkesinambungan di dalam proses pembelajaran. Penggunaan metode pembelajaran berbasis masalah serta soalsoal yang diberikan hendaknya memberikan arah untuk melatih pemecahan masalah. Sesuatu yang dilatih dengan terus menerus akan menjadikan sebuah kebiasaan, sehingga kemampuan pemecahan masalah siswa dapat tercapai secara keseluruhan. 


\section{UCAPAN TERIMA KASIH}

Penelitian dan publikasi ini didanai oleh RAPB Universitas Muhammadiyah Prof. DR. HAMKA, hibah Penelitian internal dengan nomor 801/ F.03.07 / 2021.

\section{DAFTAR PUSTAKA}

Abdiyani, S. S., Khabibah, S., \& Rahmawati, N. D. (2019). Profil Kemampuan Pemecahan Masalah Matematika Siswa SMP Negeri 1 Jogoroto Berdasarkan Langkahlangkah Polya Ditinjau dari Adversity Quotient. Al-Khwarizmi: Jurnal Pendidikan Matematika Dan Ilmu Pengetahuan Alam, 7(2), 123-134.

https://doi.org/10.24256/jpmipa.v7 i2.774

Achsin, M. (2015). Kemampuan Pemecahan Masalah Pada PBL Pendekatan Kontekstual dalam Tinjauan Inventori Kesadaran Metakognitif. Jurnal Dinamika Ilmu, 150, 696-704.

Akbar, P., Hamid, A., Bernard, M., \& Sugandi, A. I. (2017). Analisis Kemampuan Pemecahan Masalah Dan Disposisi Matematik Siswa Kelas Xi Sma Putra Juang Dalam Materi Peluang. Jurnal Cendekia: Jurnal Pendidikan Matematika, 2(1), 144-153. https://doi.org/10.31004/cendekia. v2i1.62

Anderson, J. (2014). Mathematics Curriculum Development and the Role of Problem Solving. May.

Andriyani, A., \& Ratu, N. (2018). Soal Cerita Pada Materi Program Linear Ditinjau Dari Gaya Kognitif Siswa. Jurnal Pendidikan Berkarakter, 1(1), 16-22.

Argarini, D. F. (2018). Analisis Pemecahan Masalah Berbasis Polya pada Materi Perkalian
Vektor Ditinjau dari Gaya Belajar. Matematika Dan Pembelajaran, 6(1), 91. https://doi.org/10.33477/mp.v6i1.4 48

Assidiqi, H. (2015). Membentuk Karakter Peserta Didik. Jurnal Pendidikan Matematika, 1(1), 4555.

Dahar, R. W. (2011). Teori-Teori Belajar dan Pembelajaran. Erlangga.

Erbas, A. K., \& Okur, S. (2012). Researching students' strategies, episodes, and metacognitions in mathematical problem solving. Quality and Quantity, 46(1), 89102. https://doi.org/10.1007/s11135010-9329-5

Fauzi, L. M. (2018). Identifikasi Kesulitan Dalam Memecahkan Masalah Matematika. JIPMat, 3(1), 21-28. https://doi.org/10.26877/jipmat.v3i 1.2286

Gunantara. (2014). Penerapan Strategi Pembelajaran Problem Based Learning Untuk Meningkatkan Kemampuan Pemecahahan Masalah Matematis Siswa Kelas IV. Jurnal Mimbar PGSD Universitas Pendidikan Ganesha, 10(2), 146-152. https://doi.org/10.15294/kreano.v1 0i2.19671

Hendriani, B. F., Masrukan, \& Junaedi, I. (2016). Kemampuan Pemecahan Masalah dan Karakter Mandiri Ditinjau dari Gaya Kognitif pada Pembelajaran Matematika Model 4K. PRISMA, Prosiding Seminar Nasional Matematika, 2000, 3849.

Hershkowitz, R., Hadas, N., Dreyfus, T., \& Schwarz, B. B. (2007). Abstracting processes, from 
DOI: https://doi.org/10.24127/ajpm.v10i4.3767

individuals' constructing of knowledge to a group's "shared knowledge."

Mathematics

Education Research Journal, 19(2), 41-68. https://doi.org/10.1007/BF0321745 5

Huriaty Dina. (2010). Mengembangkan Komunikasi yang efektif. $A l$ Bidayah, undefined.

Ike, F., \& Suhendri, H. (2021). Analisis Kemampuan Pemahaman Konsep Matematis Siswa Kelas V Pada Materi Kubus Dan Balok. International Journal of Progressive Mathematics Education, 1(2). https://doi.org/10.22236/ijopme.v1 i2.7308

Ikram, M., \& Ikram, M. (2021). Analysis of The Occurrence of Reversible Reasoning for Inverse Cases: A Case Study on The Subject Adjie. International Journal of Progressive Mathematics Education, 8435(1), $1-15$.

https://doi.org/10.22236/ijopme.v1 i1.6635 To

Indra, Y., Keguruan, F., Ilmu, D. a N., \& Tanjungpura, U. (2019). Operasi Hitung Pecahan Kelas V Sdn 03 Pontianak Kota Artikel Penelitian.

Irianti, N. P. (2020). Analisis Kemampuan Penalaran Siswa dalam Memecahkan Masalah Matematika Berdasarkan LangkahLangkah Polya. MUST: Journal of Mathematics Education, Science and Technology, 5(1), 80. https://doi.org/10.30651/must.v5i1. 3622

Irianti, N. P., Subanji, S., \& Chandra, T. D. (2016). Proses Berpikir Siswa Quitter dalam Menyelesaikan Masalah SPLDV Berdasarkan
Langkah-langkah Polya. JMPM: Jurnal Matematika Dan Pendidikan Matematika, 1(2), 133. https://doi.org/10.26594/jmpm.v1i 2.582

Karim, A., Soebagyo, J., \& Edy Purwanto, S. (2021). Stochastic Block Model Reveals Maps of In Applied Mathematics Studies Using VOS Viewer. International Journal of Progressive Mathematics Education, 1(2), 127142.

https://doi.org/10.22236/ijopme.v1 i2.6917

Kosiret, A., Indiyah, F. H., \& Wijayanti, D. A. (2021). The Use of Generative Learning Model in Improving Students' Understanding of Mathematical Concepts of Al-Azhar 19 Islamic High School. International Journal of Progressive Mathematics Education, 1(1), 16-26. https://doi.org/10.22236/ijopme.v1 i1.6593

Kurniasih, N., Hidayani, F., \& Muchlis, A. (2021). Analisis Kemandirian Belajar Matematika Siswa SMA Kelas XI Selama Pembelajaran Jarak Jauh. International Journal of Progressive Mathematics Education, 1(2), 117-126. https://doi.org/10.22236/ijopme.v1 i 2.6568

Lamb, J. H. (2010). Reading gread levels and mathematics assessment: an analysis of Texas mathematics assessment items and their reading difficulty. The Mathematics Educator, 20(1), 2234.

Lewier, F., Tutuhatunewa, E., \& Mataheru, W. (2019). Profil Hasil Belajar Siswa Pada Materi Perbandingan Melalui Penggunaan Model Quantum Teaching Di 
Kelas Vii Smp Negeri 6 Ambon. JUPITEK: Jurnal Pendidikan Matematika, 1(1), 32-40. https://doi.org/10.30598/jupitekvol 1iss1pp32-40

Maarif, S., Setiarini, R. N., \& Nurafni, N. (2020). Hambatan Epistimologis Siswa dalam Menyelesaikan Masalah Sistem Persamaan Linear Dua Variabel. Jurnal Didaktik Matematika, 7(1), 72-89.

https://doi.org/10.24815/jdm.v7i1. 15234

Mairing, J., Budayasa, I., \& Juniati, D. (2011). Profil Pemecahan Masalah Siswa Peraih Medali OSN Matematika. Jurnal Pendidikan Dan Pembelajaran (JPP), 18(1), 57-64.

Mardhiyana, D., \& Sejati, E. O. W. (2016). Mengembangkan Kemampuan Berpikir Kreatif dan Rasa Ingin Tahu Melalui Model Pembelajaran Berbasis Masalah. PRISMA, Prosiding Seminar Nasional Matematika, 1(1), 672688.

Maulidya, A. (2018). Berpikir Asosiatif, yaitu suatu ide merangsang timbulnya ide-ide lain. 1, 11-29.

Mawaddah, S., \& Anisah, H. (2015). Kemampuan Pemecahan Masalah Matematis Siswa Pada Pembelajaran Matematika dengan Menggunakag) di SMPn Model Pembelajaran Generatif (Generative Learning) di SMP. EDU-MAT: Jurnal Pendidikan Matematika, 3(2), 166-175. https://doi.org/10.20527/edumat.v3 i2.644

Miles, M. B., \& Huberman, A. M. (1994). Qualitative data analysis: An expanded sourcebook. In CEUR Workshop Proceedings (Vol. 1304, pp. 89-92). SAGE
Publications.

Mulyati, T. (2016). Kemampuan Pemecahan Masalah Matematis Siswa Sekolah Dasar (Mathematical Problem Solving Ability of Elementary School Students). EDUHUMANIORA: Jurnal Pendidikan Dasar, 3(2), 120.

Nabilah, E., Azhar, E., Purwanto, S. E., \& Nabilah, E. (2021). Kecemasan Siswa Dalam Menyelesaikan Masalah Modelling Matematika Pada Praktek Kelas Virtual. Internatioinal Journal of Progressive Mathematics Education, 1(1), 41-60. https://doi.org/10.22236/ijopme.v1 i1.6595

NCTM. (2000). A Vision for School Mathematics. Principles and Standards for School Mathematics, 3-8.

Nuriadin, I. (2021). Analysis of Students Mathematical Reasoning Abilities on Number Topics. Psychology and Education Journal, 58(1), 4750-4755. https://doi.org/10.17762/pae.v58i1. 1634

Nuriadin, I., Kusumah, Y. S., Sabandar, J., \& Dahlan, J. a. (2015). Enhancing Of Students' Mathematical Reflective Thinking Ability Through Knowledge Sharing Learning Strategy In Senior High School. International Journal of Education and Research, 3(9), 255-268.

Okenews. (2018). Indonesia Gawat Darurat Matematika. Https://News.Okezone.Com/Read/2 018/11/12/65/1976537/IndonesiaGawat-Darurat-Matematika.

Phonapichat, P., Wongwanich, S., \& Sujiva, S. (2014). An Analysis of Elementary School Students' 
Difficulties in Mathematical Problem Solving. Procedia Social and Behavioral Sciences, 116(2012), 3169-3174. https://doi.org/10.1016/j.sbspro.20 14.01.728

Purwanto, S. E. (2014). Pengaruh Pendekatan Open-Ended Terhadap Kemampuan Komunikasi Matematis Peserta Didik. Sigma Journal, VI(1).

Rani, A. M., \& Istiqomah, I. (2019). Profil kemampuan pemecahan masalah matematika Materi Vektor. Prosiding SENDIKA, 1(1). Ranti, M. G., Budiarti, I., \& Trisna, B. N. (2017). Pengaruh Kemandirian Belajar (Self Regulated Learning) Terhadap Hasil Belajar Mahasiswa Pada Mata Kuliah Struktur Aljabar. Math Didactic, 3(1), 7583.

https://doi.org/10.33654/math.v3i1 .57

Risani, R. T., \& Nuriyatin, S. (2021). Profil Pemecahan Masalah Matematika Siswa Ditinjau. Jurnal Penelitian Pembelajaran Matematika, 14(2), 13-20.

Sabaruddin. (2019). Penggunaan Model Pemecahan Masalah Untuk Meningkatkan Kemampuan Berpikir Aanalisis Peserta Didik Pada Materi Gravitasi Newton. Lantanida Journal, 7(1).

Saida, A., Ikram, M., Saida, A., \& Ikram, M. (2021). Analysis of Students ' Creative Thinking in Solving Cuboid Problems Analysis of Students ' Creative Thinking in Solving Cuboid Problems. International Journal of Progressive Mathematics Education, 1(2), 104-116. https://doi.org/10.22236/ijopme.v1 i2.7307
Sanders, S. (2016). Critical and Creative Thinkers in Mathematics Classrooms. Journal of Student Engagement: Education Matters, 6(1), 19.

Saputri, R. A. (2019). Analisis Pemecahan Masalah Soal Cerita Materi Perbandingan Ditinjau Dari Aspek Merencanakan Polya. Wacana Akademika: Majalah Ilmiah Kependidikan, 3(1), 21-38.

Sari, L., \& Maidiyah, E. (2019). Proses Pemecahan Masalah Matematis Siswa Smp Materi Bentuk Aljabar Melalui Model Problem-Based Learning. Jurnal Peluang, 7(2), 77-84. https://doi.org/10.24815/jp.v7i2.15 099

Schleicher, A. (2018). PISA 2018 Insights and Interpretations. 24(1), 12-17.

Tan, L. S., \& Ang, K. C. (2016). A school-based professional development programme for teachers of mathematical modelling in Singapore. Journal of Mathematics Teacher Education, 19(5), 399-432. https://doi.org/10.1007/s10857015-9305-z

Tisngati, U. (2015). Proses berpikir reflektif mahasiswa dalam pemecahan masalah pada materi himpunan ditinjau dari gaya kognitif berdasarkan langkah polya. Beta:Jurnal Tadris Matematika, 8(2), 142-152.

Tohir, M. (2019). Hasil PISA Indonesia Tahun 2018 Turun Dibanding Tahun 2015. December 2019, 2022. https://doi.org/10.31219/osf.io/pcjv $\mathrm{x}$

Umam, K. (2018). Peningkatan Kemampuan Berpikir Matematis Siswa melalui pembelajaran 
DOI: https://doi.org/10.24127/ajpm.v10i4.3767

Reciprocal Teaching. Jurnal Pendidikan Matematika Indonesia, 3(2), 57-61.

Umam, K., \& Kowiyah, K. (2018). The Effect of Non-Routine Geometry Problem on Elementary Students Belief in Mathematics: A Case Study. JETL (Journal Of Education, Teaching and Learning), 3(1), 99. https://doi.org/10.26737/jetl.v3i1.5 52

Wahyu Hidayat, R. S. (2018). Kemampuan Pemecahan Masalah Matematis dan Adversity Quotient Siswa SMP Melalui Pembelajaran Open Ended. Jurnal JNPM (Jurnal Nasional Pendidikan Matematika), 2(1), 109. https://doi.org/10.1016/S09628479(96)90008-8

Wang, P. \&. (2003). Middle school children's strategic behavior: Classification and relation to academic achievement and mathematical problem solving. Instructional Science, 31(6), 419449.
Widodo, S. A. (2013). Analisis Kesalahan Dalam Pemecahan Masalah Divergensi Tipe Membuktikan Pada Mahasiswa Matematika. Jurnal Pendidikan Dan Pengajaran, 46(2), 106-113. Yarmayani, A. (2016). Analisis Kemampuan Pemecahan Masalah Matematis Siswa Kelas Xi Mipa Sma Negeri 1 Kota Jambi. Jurnal Ilmiah Dikdaya, 6(2), 12-19.

Zhang, D., Ding, Y., Barrett, D. E., Xin, Y. P., \& Liu, R. De. (2014). A comparison of strategic development for multiplication problem solving in low-, average-, and high-achieving students. European Journal of Psychology of Education, 29(2), 195-214. https://doi.org/10.1007/s10212013-0194-1 